\title{
The Concept of Health and Wholeness in Traditional African Religion and Social Medicine
}

\author{
Onah Gregory Ajima* and Eyong Usang Ubana \\ Department of Religious Studies, University of Calabar, Calabar CRS, Nigeria
}

\begin{abstract}
African Traditional Religion and medicine are integral parts of life and culture of the Africans and have greatly influenced their conceptions about human health and wholeness. Their many realities that Africans have not been able to abandon, in spite of the allurements of western civilization, Christianity, Islam and the advances in the bio-medical sciences. The aim of this paper is to highlight the meaning of health and wholeness as central issues of concern in African Traditional Religion and Medicine. The misconception, abuse and derogatory attitudes even from some notable Africans towards alternative medicine, as well as the all need of integrating both the alternative and orthodox medicine to bring about total wholeness, serves as the research problem. This paper argued that the bio-psycho-socio-ecological model of health and wholeness is fundamental to the African Traditional Religion and Medicine. This model brings together the different aspects of human life and treats the human person as an integral and harmonious whole in perpetual relationship with the sacred, the human community and the environment. This paper therefore recommends that first, Africa has to open to modern medical discoveries and practices and secondly, African Traditional Religion and Medicine concern should be mainstreamed into the medical practice in health care services in contemporary Nigeria. It finally conclude that the alternative medicine despite the arrays of it inadequacies, objections and misconceptions, the practice has come to stay.
\end{abstract}

Keywords: Health; Wealth; Social; Pain

\section{Introduction}

Good health and wholeness of being are phenomena of universal and perennial human interest. However, people of different cultures view these concepts differently. Culture, which is a system of ideas, an integrated pattern of beliefs and behavior and a shared way of life of a people contains their worldview and determines their notion of human life. Whatever concerns human life as well as the religious, socioeconomic and environmental conditions that make that life possible? It also acts as a template for the organization of social psychological, rational, political, economic, religious and even medical processes of a people. Before the advent of European and Arabic cultures brought into Africa, Christianity and Islamic religions, Traditional African societies had their own unique culture and religion. Consequently, Africans had their unique perception about issues of health, wholeness, illness and death. What they believed to be the cause of disease and disharmony, how they also approached the promotion of health and harmony, how they experienced and expressed illness pain and disorientation of being, what therapeutic solution they sought and the places they sought these therapy where all determined by their culture of which religion was an integral part [1]. These facts still persist today and must be taken into consideration before any meaningful discussion can be made on the issue of health and wholeness.

The second point that poses as a problem, is the issue of fake and substandard orthodox medicine as well as expired ones whose label are altered, hence leading to ineffectiveness in its curatic purposes. Once in crisis situation, people tend to accuse one another of all manners of evil simply because their ailment had defiles cure when actually the problem is from the fake, substandard and expired drugs. There is also a misconception of African traditional medicine by westerners and some Africans who must have been influenced by colonial mentality to the effect that anything alternative medicine is fetish, pagan and heathen. Hence, the need for this research

The aim of this paper is to highlight the meaning of the concept of health and wholeness of being in African Traditional Religion and
Medicine. The method of this study would be mainly explorative and descriptive. This paper would highlight the meaning, characteristics and dimensions of health and wholeness in African Traditional societies. Emphasis would be placed here on the religio-medical institutions, ritual practices and agents involved in this quest for health and wholeness. It may be worthwhile too to highlight the factors traditionally believed in Africa to inhibit health and wholeness especially in our contemporary Nigerian context. Finally, recommendations would be made on how to strike a harmony between the old and new ways of religion and medicine as far as human health and wholeness are concerned.

\section{Definition of Terms/Clarification of Concepts}

Etymologically, the word health is derived from an old English or Anglo-Saxon word 'hal' or 'hael' which meant; 'health', 'whole' and 'holy'. The context to which the word was used differentiated the particular meaning then. Overtime, the word has therefore come to mean... completeness and perfection of organization, fitness of life, and freedom of action, harmony of functions, vigor and freedom from all stain, unholy corruption and disease. Even the word to heal which means to restore to a state of wholeness, soundness or integrity is derived from the same root word 'hal. The word holy also implies wholeness and purity of mind and spirit.

The concept of health generally is complex as it is elusive, non static and difficult to define. Its definition is equally highly contested and

${ }^{*}$ Corresponding author: Onah Gregory Ajima, Department of Religious and Cultural Studies, University of Calabar, Calabar CRS, Nigeria, Tel+08033125487; E-mail: drgreg.onah@yahoo.com

Received June 05, 2018; Accepted June 26, 2018; Published July 02, 2018

Citation: Ajima OM, Ubana EU (2018) The Concept of Health and Wholeness in Traditional African Religion and Social Medicine. Arts Social Sci J 9: 388. doi: 10.4172/2151-6200.1000388

Copyright: ( 2018 Ajima OM, et al. This is an open-access article distributed under the terms of the Creative Commons Attribution License, which permits unrestricted use, distribution, and reproduction in any medium, provided the original author and source are credited. 
varied. So far, there is yet no unanimity as to what could generally be accepted as the definition of health. Norman Sartorius makes it more explicit when he holds that [2]:

Today, three types of definition of health seem to be possible and are used. The first is that health is the absence of any disease or impairment. The second is that health is a state that allows the individual to adequately cope with all demands of daily life (implying also the absence of disease and impairment). The third definition states that health is a state of balance, an equilibrium that an individual has established within himself and between himself and his social and physical environment (662).

For Boruchovitch and Mednik the view of health has been identifiably prominent among scholars v12; the traditional medical concept of health, the world health organization concept and the ecological concept of health [3]. The traditional medical concept of health merely restricts the meaning of health to the absence of disease and illness. On the contrary, the World Health Organization (WHO), defines health as a state of complete physical, mental and social well being and not merely the absence of disease or infirmity, WHO went beyond the disease free mentality to conceptualize health more in a holistic manner, incorporating the physical, the psychological and the social aspect of the human life. The ecological concept of health which underscores the relative nature of the concept and the fundamental inter relationships that exist between the environment and the individual or community quality of life is what concerns the African man. To the Africans, the issue of individual ability to function well and adapt to the environment are also emphasized by the notion of health and wholeness in African Traditional Religion and medicine. To some scholars, the state of health and disease are expressions of the success and failure experienced by the organism (in this case, humans in its effort to respond adaptively to environmental changes [4].

According to Lyon and Chamberlain avers that the concept of health and wholeness can be approached using models and perspectives. In terms of models, the following have been put forward; the medical model, the social model, the holistic model and the bio-psychosocial model. The medical model is also known as the inomedical, the inological or the Western scientific medical model, sees health only from its point of view of the absence of disease or ailment or physiological abnormality. Its major presuppositions are the notion of health characteristic of western medical science. This notion of health is intrinsically scientific, mechanical, individualistic, dualistic and reductionist in nature. It views health only in terms of pathology, disease, diagnosis and treatment. This view of health construes the physical body as being separate from the social or psychological processes. The social model sees health as being the consequences of many social, economic, political, cultural and environmental factors, and working together to affect an individual. The emphasis is not so much on the individual alone but on the society and how it affects and shares responsibility in the health of the individual. Factors such as the individuals lifestyle choices, access to healthcare services, employment and social status, religion and gender can influence a person's health and his attitude towards health issues. The holistic model pays attention to the bio-physical, the psychological, the spiritual and the social aspects of the health of the individual. The bio-psycho-social model is a model that combines all the elements of the medical, social and the holistic models and is built on the premise of the interaction between all of them. It was developed by George L Engel , a psychiatrist in the university of Rochester around the 1970s. This model simply holds that:

Biological (e.g. genetic predisposition), psychological or behavioral (e.g. lifestyles, explanatory styles, health beliefs) and social factors (e.g. family relationship, socio economic status (SES) social support) are all implicated in the various stages of pathogenesis and health etiology... it is an attempt to incorporate the patients psychological experience and the social or cultural context into a more comprehensive framework for understanding disease, illness and health [5].

The above aversion is perfectly in line with the African concept of health and wholeness, to the Africans being healthy entails all facets or areas of human life (social, economic, physical, psychological, cultural, emotional, intellectual, spiritual and even occupational. Most Africans go along way to get cured by all means thereby creating room for consultation of the gods through native doctors, sorcerer and any other means possible to regain health in traditional African societies.

\section{African Traditional Religion (ATR)}

The system of beliefs, practices, rituals and symbols through which the Africans relate with the sacred, make meaning of reality as a whole and cope with the ultimate experience of the lives is what is generally referred to as African Traditional Religion. More so, it is the indigenous religious beliefs and practices of the African people. It is described as Indigenous because it is the beliefs and convictions which originated and are nurtured as well as sustained by Africans, on African soil, or carried out of Africa by Africans. Ekpunobi and Ezeaku (1990:1), writes that the fact of its origin and practices is the reason, why it is called African. Therefore, it is the traditional religious heritage of the Africans, handed down from generation to generation. In characterizing African religion, Booth, N. prefers to talk of unifying concepts which underlies specific beliefs, myths, symbols and rituals that make up the phenomenon call African Traditional Religion [6,7]. These concepts according to him includes; vitality or life -power, humanism, wholeness, continuity, health and healing as well as celebration (6-10). It is informative that health and wholeness are integral part of African Traditional Religion. It is therefore from the purview of this religious mentality that we can better appreciate the dynamics of the African notions of health and wholeness and the medical practices that promote, protect and sustain them.

\section{African Traditional Medicine (ATM) or Alternative Medicine}

African Traditional Medicine or Alternative Medicine refers to the cumulative knowledge and practices among the Africans whether explicable or not, used in the diagnosis, prevention and elimination of physical, mental or social imbalance and the restoration of health and weakness. It is tagged traditional because, it is based on knowledge, practical experience and observations handed down from generation to generation, either verbally or in written form, from African forebears.

Medicine is an important aspect of African Traditional Religion. African Traditional medicine covers both natural healing agencies such as leaves, roots, herbs; and the invocation of ritual or spiritual influences that are thought to be associated with them [8]. African medicine is directed at healing or curing of diseases as well as changing the condition of the person desirous of it. More so, medicine in a broad sense (African worldview) deals with everything that can be used to heal, kill or posses, power, health, fertility, personality, to maintain order or cause disorderliness. In order words, medicine consists of drugs for curing and preventing diseases as well as objects with ritual effects. Ikenga -Metuh also defined medicine within our conceptual framework; as the practice of medicine to include herbal as well as psychotherapeutically and spiritual technique-herbal mixtures, ritual 
objects, incantations and rites capable of changing the human condition for better or for worse [9].

Traditional African medicine is grouped with good and bad medicines; it's a good medicine if it cures and heals while the bad medicine is used for harm. Our concern here is the good medicine that brings about health and wholeness.

\section{Health and Wholeness in Traditional African Society}

African culture is interwoven with its religion thereby influencing the people's notion of health and wholeness. The belief of the existence of a supreme being, supernatural forces, origin, meaning and the ultimate purpose and destination of human life greatly influence their concept of health and wholeness. Sickness in any individual in the African society is viewed as sickness to the entire community because of the communal system that is operated in Africa, thereby necessitating the healing of that community.

Healing is a part of the complex religious attempt by Africans to bring the spiritual and physical aspects of the universe as well as man who lives in it, into a harmonious unity and wholeness. Wholeness is therefore the underlying focus of African medicine. Human life in Africa is viewed as essential and valuable. These can be seen through the elaborate protective measures and strict cautions among several ways recommended for effective and happy sojourn on earth.

\section{According to Bernard Harring [10]:}

A comprehensive understanding of human health includes the greatest possible harmony of all human faculties and energies. The greatest possible spiritualization of mans bodily aspect and the finest embodiment of the spiritual. True health is made manifest in the self actualization of that level of freedom which nourish and guide human potentials and resources for human vocations and fulfillments.

For man to be in good health, he must control his cravings, be spiritually upright as a means to please other mystical forces that may cause him illness. Against such backdrop of intersection of both human and supernatural causes of illness that makes healing process in Africa stretch from one dimension of life to another as a means for proper individual and societal functioning. It is on this that Udechukwu posits that;

For the Africans, the entire world is one fluid, coherent unit in which spirits, plants, animals, the elements, the dead and human beings interact. There is a thin line between any two sections of reality...man strives all times to maintain a harmonious relationship with all the forces that impinge on his life and being... wooing of benevolent forces and keeping in check of malevolent ones...

\section{Traditional or Alternative Medicine Practices in Africa}

Africa is enriched with traditional medical practices that enhance healthy living. The following are practices of medicine in African Traditional societies; General medicine men, Psychiatrists, bone setters, traditional birth attendants, diviners, magicians, as well as sorcery and witchcraftcy. For the sake of this paper, we will look at a few fore mentioned traditional medical practices;

\section{Divination, medicine and wholeness}

Divination is the practice of determining the hidden significance or cause of events by various natural, psychological and other techniques... Merriam-Webster's Encyclopedia of World Religion [11]. The techniques of divination enable humans to have insight and knowledge of the future, or about things that may be mysterious or hidden. Following its divine roots, divination relates to the super sensible world.

In African Traditional Medicine, divination is used by diviners and medicine men use various forms of divination to unravel and diagnose their clients. Through such device, the medicine man is guided by the best way of solving the client problem. The following are the ways of divination; through dreams, visions, body actions, ordeals, spirit possession, necromancy, animal types, mechanical technique, nature divination and sundry ways of divination technique [12].

\section{Magic, medicine and wholeness}

Magic in Africa is another perspective, concomitant and structural property of medicine and wholeness. Magic is viewed as a religious phenomenon, it is a special way of human beings manipulation of the supernatural to their own benefit. 'magic is the use of material objects or medicinal plants and the invocation of verbal formulae to control and manipulate events and the surrounding world' [13]. In African Medicine and use of magic, man is aimed at projecting his ego, using ritual objects, spells and rites to influence the divine and supernatural powers for his will to be done.

In traditional African Medicine, magic is interconnected with divination as a means to discover or diagnose ailments and means to treat such disease.

\section{Witchcraft and sorcery in African medicine}

Witchcraft and sorcery are two aspects of African medicine and wholeness that are prevalent in African religion. A typical African is superstitious; he believes not in coincidence but sees reason for every occurrence in human endeavor. Witchcraft and sorcery are aspects of "bad magic" that is used in manipulating the power of bad spirits for medicine making. However, both means can be used negatively to harm humans in the African society. Mbiti, J. wrote to buttress this fact when he avers that 'witches, evil magicians and sorcerers are the most hated (not often feared) persons in our communities' [14]. Sorcery and witchcraft are used in most cases to hunt and harm enemies and most people go a long way to acquire certain objects or shrines to become witches and wizards as a means to protect themselves or their entire family from other harmful witches or sorcerers.

\section{Traditional birth attendants (TBAs)}

Traditional birth attendants in African traditional health care systems are equivalent to midwives and gynecologists in the orthodox medicine. They are tested with the skills and knowledge through experience the act of helping mothers at childbirth. In most religions in Africa because of religious beliefs, most TBAs are females as a means to protect womanhood. These TBAs are endowed with the skills and experience to perform both prenatal and post natal care to pregnant and nursing mothers. Their dedication to service is epitomized and held in high esteem. They see their role as a means to contribute their quota to the functioning of the society. The delivery through caesarean section is very rare, exemplifying their successes in delivery methods. Most TBAs administer reproductive medicine to enhance fertility in traditional African setting.

\section{Bone setters}

Bone setters in African Traditional Medicine are equated to perform the function of orthopedics in orthodox medicine. They specialize in 'fixing' fractured bones and dislocations. Traditional bone setters are those knowledgeable in the art and skill of setting broken bones in 
the traditional way, using their skills to see that bones unite and heal properly.

They use herbs, roots, barks and different types of human bones, which are respectively used to handle similar parts of the body of the living. Most traditional bone setters make pain relief medicine and rituals for the healing of their clients; they effectively handle referral cases from orthodox hospitals. There have been reported cases of fractures resulting from motor accidents or falls from trees and other causes of fracture that are referred to traditional bone setters for treatment. An interesting aspect of bone setters approach is the selection of a chicken whose leg could be broken and reset in most fracture cases. The fracture caused on the chicken is treated alongside that of the patient at the same time and in the same way. This is usually used to determine the time the patient's fracture will heal, and the time to remove the wrapped splints and clay caste that help in holding the fractured bone in place. It is particularly note worthy that traditional bone setters are often capable of arresting the deterioration of gangrenous limbs that may lead to amputation, this treat makes amputation rare when compare bone setting in traditional African societies to the orthodox medicine or specifically the orthopedics surgery. This treat stands out when African traditional medicine is compared to orthodox medicine even in contemporary times.

\section{Traditional psychiatrists}

Traditional psychiatrists are those in African traditional medicine that specializes in the treatment of mental disorder or the treatment of lunatics. They treat mental disorder by restraining violent patients with either wooden shackles or chains as a means to control patients that are possessed with demonic spirits. In most cases, patients are caned or beaten to submission or given herbal hypnotics or highly sedative herbal potions to calm them. They combined both physical strategies and techniques as means through which the healing of their patients are attained. Most psychiatric hospitals recommend traditional psychiatric treatment in cases they cannot handle. The efficiency of the traditional psychiatrist in the African society tells more of its usefulness and as a reasonable alternative even to the orthodox psychiatric hospitals.

\section{Factors that inhibit health and wholeness in Africa}

Health and wholeness in Africa covers a broad range of tapestry of individuals, family, social and spiritual restoration [15]. Health and wholeness in Africa is believed to be hampered or inhibited by any factor that threatened the established harmony in the cosmic communal family of individuals life. Underpinning all these factors, however are issues which border on morality and religion. Adefolagu, T. remarks that 'the general belief in African traditional medicine is that illness is not caused by germs but by the breach of natural laws. The restoration of this law through, confession and performance of rituals, and in most cases payment of fines will help to restore, maintain and correct human disorder'. Human actions and activities that breach both stipulated moral codes in the society are capable of breaching moral codes and societal harmony, resulting to breakdown of spiritual, emotional, social, environment or biophysical, drought, flood, poor harvest, infertility, being beaten by a snake, leprosy, killed by a falling tree and other serious human ailments could be mentioned among the environmental and biophysical problems that are attached to failure of humans to fulfill their human obligation (i.e not doing or fulfilling an action prescribed to individuals or family or even society). Iyalomhe and Iyalomhe avers that in Africa;

"Ill health and other misfortunes can result as a disturbance in the relationship between man and his social cum spiritual environment, or from forces directed by witches, wizards, sorcerers, evil spirits or angered ancestors because of infraction of totemic principles. The popular notion is that "people do not just suffer illness by chance" therefore serious illness is believed to have its origin in a primary supernatural cause. There is no difficulty, however, in accepting biomedical explanations based on the presence of viruses, bacteria, parasites, cancer or high blood pressure, there are simply seen as secondary causes. The idea of primary causation provides explanation as to why a particular individual and not others in the group is affected by these infectious agents.

\section{African traditional religion and medicine and the question of health and wholeness in modern time}

There is no doubt that the question of life, health, well being and wholeness are central in traditional African societies. It is a universal human need predicated on the primary instinct of survival common to all living things. These instincts of survival have motivated medical scientific discoveries and technology to eradicate dreaded disease or brought such under human control. In spite of these modern advances, most people in Africa still fall back to traditional African medicines which now operate side by side with the orthodox and western biomedical practices that made their entry during the colonial era bringing about medical pluralism in Africa. Medicines from various traditions have been brought into serious clash and competition as a result of dosage and other issues patterning African traditional medicine. Even in this competition, African traditional medicine is gaining an upper hand and still maintains a resilient posture. A vast majority of Nigerians and of course most Africans, for instance still have a strong belief and reliance on the services of the traditional practitioners for their health care needs. These can be seen in the high degree of patronage among Nigerians. According to Nchinda T More so, many see traditional medicine and orthodox medicine as different polar of the same thing-health [16].

Several ailments and sicknesses exist that orthodox medicine and personnel cannot cure, hence they are ignorant of their causation and diagnosis, but are referred to traditional medicine for solutions. Another case is the issue of traditional bone setters; they tend to proffer solutions to accidents that concern amputation in orthodox medicine. Despite the criticism raised on issues of hygiene, sterile rules, surgery, incision, dosage prescription and administration in African medicine, several advantages still exist to encourage Africans to patronize their indigenous medicine as a result of its cheap and availability and effectiveness. Most traditional medical practices are being empirically tested and given the financing to meet the approved standards as means to encourage traditional medicine as a vital alternative to orthodox medicine. Through African traditional medicine, sickness and ailment in African concept is properly addressed as physical, psychological, social, and economic and several other avenues of ill health are addressed areas which orthodox medicine tends to neglect.

\section{Conclusion}

African traditional medicine has come to stay despite the array of objections and negative compliments it received in time past and in fact still receives. It had strived and prospered in modern time. The alternative medical services have provided challenges to the orthodox medical practices all over Africa even in recent times. To Africans, health and wholeness can only be attained when all issues that affect and influence man are addressed, an issue which only traditional medicine can only provide (spiritual, physical, social, economic, 
Citation: Ajima OM, Ubana EU (2018) The Concept of Health and Wholeness in Traditional African Religion and Social Medicine. Arts Social Sci J 9: 388. doi: 10.4172/2151-6200.1000388

Page 5 of 5

psychological, etc). African traditional medicine should be integrated and allowed to function side by side with orthodox medicine as a viable alternative or substitute as a means to facilitate quick recovery during illness of persons in Africa or the world at large. It is also necessary that the Faculty of Medicines in African Universities introduce alternative medicines as a degree programme in our tertiary institutions to advance and enhanced these aspects of health care that have been bastardised, misrepresented, abused, but which still remain relevant, practical and beneficial to many. African traditional medicine has come to stay despite the array of objections.

\section{References}

1. Napier D (2014) Culture and Health. The Lancet Commission 384: 1607-1638.

2. Sartorius, Norman (2006) The meaning of Health and its promotion. Croat Med J 47: 662-664.

3. Boruchovitch E, Mednick BR (2002) Meaning of Health and Illness: some considerations for health psychology. Psico-UST 7: 175-183.

4. Dubos R (1965) Man adapting New Haven: Yale University pp: 17-19.

5. Hatala A (2012) The status of the Biopsychosocial model in Health Psychology: towards an integrated Approach and critique of cultural conceptions. Open Journal of Medical Psychology pp: 51-62.

6. Ekpunobi Emma, Ezeaku Ifeanyi (1990) Socio-philosophical perspective of African Traditional Religion. Enugu: New Age publishers.

7. Booth N (1979) African Religions New York: NOK Publishers International pp: 6-10.

8. Parrinder G (1969) African's three Religions London: Sheldon Press.

9. Ikenga-ME (1981) God and man in African Religion London: Geoffrey Chapman.

10. Bernard H (1972) Medical Ethics England: stPaul's publications.

11. Merriam (1999) Webster Encyclopedia of World Religion Massachusetts Miriam -Webster incorporated.

12. Collins John (1978) Primitive Religion Totowa NJ: Littlefield Adams and Co.

13. Moris B (2006) Religion and Anthropology: a critical introduction New York: Cambridge University Press.

14. Mbiti J (1969) African Religions and Philosophy London: Heinemann.

15. Hucks P, Tracy E (2013) Habitations of the Sacred: African approaches to disease and healing complex disease. Havard Divinity Bulletin Autumn Vol-41.

16. Nchinda T (1976) Traditional and Western Medicine in Africa: collaboration or confrontation? Topical Doctors 6: 133-138. 